\title{
INFLUENCE OF FAMILY LIFE ON THE COURSE OF SCHIZOPHRENIC ILLNESS
}

\author{
BY \\ G. W. BROWN, E. M. MONCK, G. M. CARSTAIRS, AND J. K. WING \\ Medical Research Council Social Psychiatry Research Unit, Institute of Psychiatry, Maudsley Hospital, London
}

Much of the literature on the family of the schizophrenic patient has suggested that a number of common features are present in the personalities of the parents, and that these are significant in the aetiology of the illness. Most studies have been concerned with the parent-child relationship and only a few with the adult patient and his parents. Tietze's description of mothers as generally' over-anxious, obsessional, and domineering is typical (Tietze, 1949); and Fromm-Reichmann (1948) coined the term "schizophrenogenic" to describe such women. The more systematic work has indicated a high frequency of domineering and over-solicitous behaviour among mothers (Mark, 1953; Freeman and Grayson, 1955; Gerard and Siegel, 1950; Kohn and Clausen, 1956). Two studies, however, have produced negative evidence (Neilsen, 1954; Hotchkiss, Carmen, Ogilby, and Wiesenfeld, 1955) and the second of these was the only one in which the behaviour of the mother and patient was directly observed.

Even if differences exist between the mothers of schizophrenics and other mothers, this need not be of aetiological importance. The possibility must first be excluded that behaviour such as "overprotectiveness" may be the result of the patient's unusual behaviour influencing the parents (Kasanin, Knight, and Sage, 1934). Once an illness has developed in one member of a family, a heightened level of tension is probably common. Once established, tense relationships in turn may have an important effect on the later stages of the illness. Some evidence that family relationships can influence the course of schizophrenia was provided by a previous study, which showed that re-admission of long-stay patients was related to the type of living group to which they returned (Brown, Carstairs, and Topping, 1958; Brown, 1959). Patients who lived with wives and parents showed a higher re-admission rate than those going to brothers, sisters, or more distant kin, or in lodgings. There was evidence that the risk of deterioration in clinical condition was increased when prolonged contact with close relatives in the house was unavoidable-when, for example, both patient and mother were unemployed. Results could not be explained entirely by the length or past severity of illness or by differences in clinical condition at the time of discharge; and it was concluded that it might not always be best for the schizophrenic patient to return to the close emotional ties of affection or hostility often found in parental and marital homes.

These close emotional ties are not, of course, confined to households of any particular kinship category. It was therefore decided to continue the work by studying the relationships within each home to which discharged patients returned. The majority of patients in this second study were short-stay schizophrenics, and a different survey method was used. Patients and their families were interviewed at the time of discharge and during the year, if the patient was re-admitted, as well as at the end of the follow-up period. In this way the difficulties inherent in the previous exploratory survey, which relied on one interview at the time of follow-up, were avoided. In particular, since patients and families were seen at discharge, predictions could be made about outcome which were not influenced by knowledge of the later course of the illness; and the clinical condition of patients (assessed at the time of discharge) could be controlled in testing the predictions. The two hypotheses were:

(1) That a patient's behaviour would deteriorate if he returned to a home in which at the time of discharge strongly expressed emotion, hostility, or dominating behaviour was shown towards him by a member of the family. 
(2) That, even if a patient returned to such a home, relapse could be avoided if the degree of personal contact with the family was small.

This paper will present only those results which are strictly relevant to the testing of these predictions.

\section{MethoD}

Eight London mental hospitals were asked to notify us of the impending departure of all schizophrenic men between the ages of 20 and 49, who had been in hospital at least one month and who were going to an address in the London area. Men going to hostels were excluded because of the difficulties of keeping in touch with them; also excluded were foreigners who could not speak English and nonEuropeans. Over a 12-month period we were given the names of 134 suitable patients. By the end of the follow-up year two men had left London and were excluded and four of the 31 men in lodgings could not be traced. A total of 128 men were finally studied.

Arrangements were made for one of the two psychiatrists (G.M.C. or J.K.W.) to see the patient a day or two before he left hospital. The psychiatrist satisfied himself that each man had had a schizophrenic illness, carried out a systematic clinical interview, and interviewed a nurse about the patient's behaviour during the previous week. If the patient was planning to live in lodgings or alone, no further contact was made until a year later or at any re-admission to hospital. If he returned to relatives, all the following interviews were held (by G.W.B. or E.M.):

(1) With his relatives before his arrival home, in order to collect background information about the family and his past behaviour, and to assess their opinions about his return.

(2) With the patient and "key" relative 2 weeks after discharge. The "key" relative was defined as the most closely related female living in the household-typically a wife or mother. Obvious exceptions were made in cases in which patients lived only with a male relative. All adult members of the household were present at 78 per cent. of the interviews ( 40 per cent. of patients lived with only one other adult). During this interview the behaviour of the patient and key relative was observed and rated. In two cases the patient left the house to avoid the interviewer, and in two others it was not known until the end of the year that the patient had returned to relatives.

(3) With members of the household on readmission of the patient, or at the end of the year if he was not re-admitted, to collect information about the patient's behaviour during the discharge period. If re-admitted, the patient was usually also seen in hospital.

\section{Description of The Four Main Scales of MEASUREMENT}

(1) Scales of Clinical Condition at Discharge

Two sets of scales referring to clinical condition were completed at the time of discharge. The first five scales described the "mental state" of the patient during an interview with a psychiatrist; the second five scales described "socially embarrassing behaviour" in the ward, the information for which was obtained from a nurse who had been caring for the patient during the previous week. The scales were as follows:

Mental State during Psychiatric Interview:

(i) Flatness and incongruity of affect;

(ii) Other affects (hostility, suspiciousness, anxiety, depression, and euphoria);

(iii) Speech disorder;

(iv) Delusions;

(v) Hallucinations.

Socially Embarrassing Behaviour in the Ward during the Previous Week:

(i) Social withdrawal;

(ii) Motor activity (under- or over-activity);

(iii) Deteriorated personal habits;

(iv) Bizarre behaviour;

(v) Anti-social behaviour.

Each of the ten scales was rated on five points of severity ranging from "not present" (1) to "markedly present" (5). However, in the presentation of results which follows, overall ratings of "mental state" and "socially embarrassing behaviour" are used. For the overall rating of "mental state", the highest rating made on any of the five component scales was used; thus a patient rated 3 on delusions, and 2 on the other four scales, would be given an overall rating of 3.

Since no symptom shown by these patients was considered sufficiently severe to warrant a rating of 5 , four groups were distinguished; patients with an overall rating of 1 were regarded as symptom-free, 
2 nearly symptom-free, 3 moderately ill, and 4 severely ill.

A similar procedure was followed in the rating of "socially embarrassing behaviour".

\section{(2) Scales of "Emotional InVolvement" (see Appendix)}

During the interview with the key relative and patient 2 weeks after discharge, questions were asked about problems connected with the patient's return, his plans for the future, and his relations with others in the home. Conversation was encouraged so that the relationship between the patient and his family could be rated. The interviewer restricted his own contribution as far as possible to simple promptings and the introduction of new topics.

It was not feasible to use techniques of observation and recording suited to laboratory situations when visiting patients in their own homes; and the elaborate methods sometimes employed in the study of small groups were not felt to be necessary at the present stage of this work. It was decided to rely on five scales for rating the relationship between patient and key relative, three referring to the behaviour of the key relative towards the patient, and two to that of the patient towards his family. The two upper ratings $(a$ and $b)$ of the following scales represent excessive behaviour, the third (c) "normal" or "minimal" evidence, and the lowest $(d)$ absence of the characteristic.

\section{(A) Emotion Expressed by Key Relative towards Patient:}

(a) Uncontrolled emotion frequently shown.

(b) Conspicuous emotion shown, but under some degree of control.

(c) Emotion shown but well controlled: noticeable only in response to some strong stimulus.

(d) No emotion expressed: evidence of indifference or casualness.

(B) Hostility Expressed by Key Relative towards Patient:

(a) Marked rejection or hostility shown in behaviour.

(b) Definite hostility, but not often observed in open form.

(c) Minimal evidence.

(d) No evidence.
(C) Dominant or Directive Behaviour by Key Relative towards Patient:

(a) Very marked and continuous.

(b) Not marked but unmistakable.

(c) "Normal" or minimal.

(d) No evidence.

(D) Emotion Expressed by Patient towards Key Relative:

(a) Uncontrolled emotion frequently shown.

(b) Conspicuous emotion shown, but under some degree of control.

(c) Emotion shown but well controlled: noticeable only in response to some strong stimulus.

(d) No emotion expressed: evidence of indifference or casualness.

(E) Hostility Expressed by Patient towards Key Relative and Other Members of Family present at Interview:

(a) Marked rejection or hostility shown in behaviour.

(b) Definite hostility, but not often observed in open form.

(c) Minimal evidence.

(d) No evidence.

(Originally the patient's hostility towards the key relative was distinguished from that towards other family members present at the interview. But, since the patient showed hostility towards other members and not towards the key relative on only four occasions, the two scales were combined.)

Ratings of emotion and hostility were made by commonsense signs, such as content of speech, tone of voice, and gesture; behaviour which took place outside the interview, or was referred to but not observed, was not used in making these ratings. A wife who had spoken at the previous interview, for example, of her hostility towards her husband but who did not show signs of this in the patient's presence would not be rated as hostile. In the rating of "dominant" behaviour, similar common-sense signs were noted, such as interruptions when the patient was talking, suggestions about what he should tell the interviewer, and orders about what he should do. Some brief examples of ratings on the five scales are given in the Appendix.

Pilot interviews were carried out in two stages. The first series of ten interviews allowed some 
amendments to be made. In a second series, sixteen patients and relatives were seen in their own homes soon after discharge by both interviewers together, and ratings were made independently. The two interviewers disagreed on seven of their 96 ratings in the sixteen interviews; on only three of these was there any discrepancy between the top and bottom half of the scale. No scale had more than two differences. This level of reliability was acceptable.

\section{(3) Deterioration in Behaviour DURINg Follow- UP YEAR}

In the interview at the end of the year or at any re-admission, with either the patient or a near relative (usually both), systematic accounts were obtained of the patient's behaviour. The same ten items were covered as were used to record the clinical condition at the time of discharge. On the basis of these ratings and of the hospital notes made at any re-admission, the interviewer was able to decide whether the patient's behaviour had deteriorated, remained much the same, or improved. Since this was the measure to be used in testing the hypotheses, a patient was rated as deteriorated in behaviour only on very clear evidence. Of those so rated, three-quarters had in fact also returned to hospital. The interviewer was, of course, helped by possessing a systematic account of the patient's condition at discharge, and also by having seen the patient a fortnight later (if he had returned to relatives). It should be stressed that this is a relative measure of outcome. Although a patient might have shown very evident symptoms at followup, if these had not clearly worsened he would be defined as not deteriorated.

\section{(4) Time Budget of Social Activities of the PATIENT}

During the final interview at the end of the year or at re-admission, the relatives or the patient (and often both) were asked in considerable detail about his everyday social activities during a typical week. Care was taken to record how the patient spent his time before any deterioration in behaviour occurred. For example, if he worked for some months but left when he became too disturbed and then remained much of the time in his own room, his activity while at work was recorded.

On the basis of pilot interviews, the waking hours in one week were divided into categories, such as time at work, time with household members, and so on. In the interview a chart with hour intervals was used to enter in detail events of the day, such as time of getting up, time spent over breakfast, travelling to work, and so on throughout each day of the week. An adjacent column was used to record with whom the patient spent his time in each activity.

A first series of ten pilot interviews showed that this could be done accurately and allowed certain alterations to be made in the categories. It was found most satisfactory to work through the activities of each day as they occurred, and to discuss the week-end separately. A second series of nine interviews was completed with members of an expatients' club who had been out of hospital some years. Each informant was seen by the second interviewer one week after seeing the first. Differences between the assessments of the two interviewers were considered to fall within acceptable limits. For example, for the measure used in this account-time spent in face-to-face contact with the key personthe average amount of time was $26 \cdot 1$ hours in one week and the average difference between the interviewers $2 \cdot 1$ hours (not statistically significant).

In order to test the two hypotheses concerning the effect on the course of the illness of strong emotional ties and of the amount of face-to-face contact between patient and family, the first three of these four measures have been somewhat simplified in the following account of the results.

\section{RESULTS}

\section{(1) Deterioration in Behaviour}

Of the 128 patients, 53 (41 per cent.) returned to hospital in the year after discharge, eleven of them more than once. The numbers returning each month for the first time remained more or less constant.

Table I shows that 52 per cent. had become definitely worse in behaviour by the end of the year or at re-admission; three-quarters of these patients

TABLE I

OUTCOME AT THE END OF THE YEAR OR AT RE-ADMISSION

\begin{tabular}{|c|c|c|c|c|}
\hline Behaviour & $\begin{array}{l}\text { Number } \\
\text { not Re- } \\
\text { admitted }\end{array}$ & $\begin{array}{l}\text { Number } \\
\text { Re- } \\
\text { admitted } \\
\text { in the } \\
\text { Year }\end{array}$ & Total & $\begin{array}{c}\text { Per- } \\
\text { centage } \\
\text { of } \\
\text { Total }\end{array}$ \\
\hline $\begin{array}{l}\text { (1) Definitely much worse } \\
\text { (2) Definitely worse } \\
\text { (3) Possibly worse.. } \\
\text { (4) Same } \ldots \\
\text { (5) Same or better, but } \\
\text { worse at times during } \\
\text { the year } \ldots \\
\text { (6) Possibly improved } \\
\text { (7) Definitely improved }\end{array}$ & $\begin{array}{r}7 \\
10 \\
2 \\
28 \\
\\
\\
8 \\
14 \\
6\end{array}$ & $\begin{array}{r}35 \\
15 \\
3 \\
\end{array}$ & $\left.\begin{array}{r}42 \\
25 \\
5 \\
28 \\
\\
8 \\
14 \\
6\end{array}\right\}$ & 32 \\
\hline All Patients & 75 & 53 & 128 & 100 \\
\hline
\end{tabular}


returned to hospital. 32 per cent. were much the same (five of these 41 patients were rated "possibly worse" and eight "same but worse at times during the year"). 16 per cent. were considered to be "possibly" or "definitely" improved at follow-up.

The patients were divided into two groups: a "deteriorated" group which included all those who were re-admitted during the year and all those who were rated as "definitely worse" at the end of the year; the remainder were defined as 'not deteriorated'. On this basis, 55 per cent. deteriorated and 45 per cent. did not.

\section{(2) Clinical Measures at Discharge and DETERIORATION}

(i) Mental State.-Deterioration, as defined above, was shown by 48 per cent. of those with no mental state symptoms at discharge, 36 per cent. of those with minimal disturbance, 67 per cent. of those with moderate disturbance, and 56 per cent. of those with severe disturbance (Table II). Because of this order of relationship with deterioration, the two least disturbed groups (1 and 2$)$ and the two most disturbed groups ( 3 and 4 ) were combined in subsequent analysis; 42 per cent. of the former and 64 per cent. of the latter group deteriorated in behaviour. This difference is statistically significant.

\section{TABLE II}

\begin{tabular}{|c|c|c|c|c|}
\hline $\begin{array}{c}\text { Disturbed } \\
\text { Mental State }\end{array}$ & $\stackrel{\text { Not }}{\text { Deteriorated }}$ & Deteriorated & Total & $\begin{array}{c}\text { Percentage } \\
\text { Deteriorated }\end{array}$ \\
\hline $\begin{array}{ll}1 \text { (None) } & \ldots \\
2 \text { (Minimal) } & . \\
3 \text { (Moderate) } & \ldots \\
4 \text { (Severe) } & .\end{array}$ & $\begin{array}{r}13 \\
18 \\
19 \\
8\end{array}$ & $\begin{array}{l}12 \\
10 \\
38 \\
10\end{array}$ & $\begin{array}{l}25 \\
28 \\
57 \\
18\end{array}$ & $\begin{array}{l}\left.\begin{array}{l}48 \\
36 \\
67 \\
56\end{array}\right\} 42 \\
42\end{array}$ \\
\hline \multirow[t]{2}{*}{ All Patients } & 58 & 70 & 128 & 55 \\
\hline & \multicolumn{3}{|c|}{$x^{2}=6 \cdot 34,1$ d.f., $p<.02$} & \\
\hline
\end{tabular}

(ii) Socially Embarrassing Behaviour.-Table III shows that 47 per cent. of those showing no distur-

TABLE III

SOCIALLY EMBARRASSING SYMPTOM RATINGS AT DISCHARGE AND PROPORTION WHO DETERIORATED

\begin{tabular}{|c|c|c|c|c|}
\hline $\begin{array}{c}\text { Socially } \\
\text { Embarrassing } \\
\text { Behaviour }\end{array}$ & $\begin{array}{c}\text { Not } \\
\text { Deteriorated }\end{array}$ & Deteriorated & Total & $\begin{array}{c}\text { Percentage } \\
\text { Deteriorated }\end{array}$ \\
\hline $\begin{array}{l}1 \text { (None) } \\
2 \text { (Minimal) } \ldots \\
3 \text { and } 4 \\
\text { (Moderate and } \\
\text { Severe) }\end{array}$ & $\begin{array}{l}28 \\
23\end{array}$ & $\begin{array}{l}25 \\
27 \\
18\end{array}$ & $\begin{array}{l}53 \\
50 \\
\\
25\end{array}$ & $\begin{array}{l}47 \\
54 \\
72\end{array}$ \\
\hline \multirow[t]{2}{*}{ All Patients } & 58 & 70 & 128 & 55 \\
\hline & \multicolumn{3}{|c|}{$x^{2}=4 \cdot 23,2$ d.f., $p>\cdot 10$} & \\
\hline
\end{tabular}

bance of behaviour in the ward at discharge, 54 per cent. with minimal disturbance, and 72 per cent. with moderate or severe disturbance deteriorated in behaviour in the follow-up year. Although these figures show the expected trend, the differences do not reach statistical significance.

\section{(3) Other Pre-Discharge Items AND Deterioration}

The analysis of the relation between other predischarge items and deterioration in behaviour after discharge will not be given here in detail, but is summarized in Table IV. From this it can be seen that deterioration was rather commoner in young patients under 20 years of age, in those with longer durations of stay in hospital, and in those with more than three previous admissions; the increased risk of deterioration was not significant in any of these categories. On the other hand a significantly greater deterioration rate was observed in those who had shown a decline in occupational level or disturbed behaviour before admission, or in those who had been unemployed for 12 months or more in the 2 years before discharge.

TABLE IV

PREDISCHARGE ITEMS RELATED TO DETERIORATION

\begin{tabular}{|c|c|c|c|c|}
\hline \multirow{2}{*}{\multicolumn{2}{|c|}{ Predischarge Items }} & \multirow{3}{*}{ 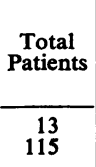 } & \multicolumn{2}{|c|}{ Deteriorated } \\
\hline & & & \multirow{2}{*}{$\begin{array}{l}\text { No. } \\
\begin{array}{l}11 \\
59\end{array}\end{array}$} & \multirow{2}{*}{$\begin{array}{c}\begin{array}{c}\text { Per } \\
\text { cent. }\end{array} \\
\begin{array}{c}85 \\
51\end{array}\end{array}$} \\
\hline $\begin{array}{l}\text { (i) } \underset{\text { mission }}{\text { Age }} \text { at } \\
\text { First }\end{array}$ & $\begin{array}{l}\text { Under } 20 \ldots \\
20 \text { and Over }\end{array}$ & & & \\
\hline $\begin{array}{l}\text { (ii) Length of Key Stay } \\
\text { (mths) }\end{array}$ & $\begin{array}{l}\text { Under } 6 \\
6 \text { and Over }\end{array}$ & $\begin{array}{l}95 \\
33\end{array}$ & $\begin{array}{l}46 \\
24\end{array}$ & $\begin{array}{l}48 \\
73\end{array}$ \\
\hline $\begin{array}{l}\text { (iii) No. of Previous Ad- } \\
\text { missions }\end{array}$ & $\begin{array}{l}\text { Less than } 3 \\
3 \text { and Over }\end{array}$ & $\begin{array}{l}87 \\
41\end{array}$ & $\begin{array}{l}43 \\
27\end{array}$ & $\begin{array}{l}49 \\
66\end{array}$ \\
\hline $\begin{array}{l}\text { (iv) Decline in Occupa- } \\
\text { tional Level before } \\
\text { Admission }\end{array}$ & $\begin{array}{l}\text { Yes } \\
\text { No } \\
\text { Not known }\end{array}$ & $\begin{array}{r}48 \\
78 \\
2\end{array}$ & $\begin{array}{r}31 \\
37 \\
2\end{array}$ & $\begin{array}{r}65 \\
47 \\
-\end{array}$ \\
\hline $\begin{array}{l}\text { (v) “Disturbed" Be- } \\
\text { haviour before } \\
\text { Admission }\end{array}$ & $\begin{array}{l}\text { Yes } \\
\text { No } \\
\text { Not known }\end{array}$ & $\begin{array}{r}55 \\
71 \\
2\end{array}$ & $\begin{array}{r}36 \\
33 \\
1\end{array}$ & $\begin{array}{l}65 \\
46 \\
-\end{array}$ \\
\hline $\begin{array}{l}\text { (vi) Months Unem- } \\
\text { ployed in } 2 \text { years } \\
\text { before Discharge } \\
\text { (including time in } \\
\text { hospital) }\end{array}$ & $\begin{array}{l}\text { Less than } 12 \\
12 \text { and Over } \\
\text { Not known }\end{array}$ & $\begin{array}{r}64 \\
63 \\
1\end{array}$ & $\begin{array}{r}27 \\
42 \\
1\end{array}$ & $\begin{array}{l}42 \\
67\end{array}$ \\
\hline
\end{tabular}

Age at discharge, length of time since first admission, and marital state at discharge showed no relationship with deterioration.

\section{(4) Emotional Involvement and Deterioration}

To test the two hypotheses concerning family relationships and deterioration, those groups of 
patients for whom the "emotional involvement" interview 2 weeks after discharge was not made (27 patients living in lodgings and four of the 101 returning to relatives) were excluded. Seventy of the patients returned to parents, 24 to wives, six to brothers or sisters, and one to a cousin.

Ratings on the five individual "emotional involvement" scales are related in the expected direction to deterioration.

(i) Scales referring to Relatives.-Table V shows the results for the three scales which describe the behaviour of the key relative towards the patient; 33 of the 97 relatives ( 34 per cent.) were rated "high" $(a$ or $b)$ on "expressed emotion", and 41 (42 per cent.) "high" ( $a$ or $b$ ) on "dominance". The proportion of patients who deteriorated in each of the four grades from high to low were, for "expressed emotion" $89,75,42$, and 22 per cent., and for "dominance" $77,57,48$, and 40 per cent. The trend on the "dominance" scale is not statistically significant.

Only ten relatives showed marked hostility ( $a$ or $b)$; and the nineteen patients who returned to relatives showing minimal hostility $(c)$ did just as badly as these ten. Of these two groups of patients, 80 and
74 per cent. respectively deteriorated, in comparison with 43 per cent. of those patients whose relatives showed no hostility $(d)$. This difference is statistically significant.

Intercorrelations between the three scales referring to the behaviour of the key relatives are very low. The only two scales to show a contingency coefficient above 0.10 were "expressed emotion" and "dominance" $-C=\cdot 41, p<\cdot 001,1$ d.f.

(ii) Scales referring to Patients.-Only four of the 97 patients showed high "expressed emotion", and three of these deteriorated (Table VI). 28 patients were rated at least minimally hostile $(a, b$, or $c)$, and 71 per cent. of these deteriorated compared with 45 per cent. of the patients who showed no hostility towards their families. This difference is statistically significant.

All four patients showing high "expressed emotion" also showed some hostility.

(iii) Relationship of Scales referring to Relatives and Scales referring to Patients.-The scale referring to patients' hostility showed a definite relationship with the scales of relatives' behaviour; 23 (82 per cent.) of the 28 patients rated as at least minimally

TABLE V

BEHAVIOUR OF KEY RELATIVE AND PROPORTION OF PATIENTS WHO DETERIORATED

\begin{tabular}{|c|c|c|c|c|c|c|c|c|c|c|c|c|c|}
\hline \multicolumn{5}{|c|}{ A. Expressed Emotion } & \multicolumn{5}{|c|}{ B. Hostility } & \multicolumn{4}{|c|}{ C. Dominance } \\
\hline \multirow{2}{*}{\multicolumn{2}{|c|}{ Grade }} & \multirow{2}{*}{$\begin{array}{l}\text { Total } \\
\text { in } \\
\text { Grade }\end{array}$} & \multicolumn{2}{|c|}{$\overline{\text { Deteriorated }}$} & \multirow{2}{*}{\multicolumn{2}{|c|}{ Grade }} & \multirow{2}{*}{$\begin{array}{l}\text { Total } \\
\text { in } \\
\text { Grade }\end{array}$} & \multicolumn{2}{|c|}{ Deteriorated } & \multirow[b]{2}{*}{ Grade } & \multirow{2}{*}{$\begin{array}{l}\text { Total } \\
\text { in } \\
\text { Grade }\end{array}$} & \multicolumn{2}{|c|}{ Deteriorated } \\
\hline & & & No. & $\begin{array}{l}\text { Per } \\
\text { cent. }\end{array}$ & & & & No. & $\begin{array}{c}\text { Per } \\
\text { cent. }\end{array}$ & & & No. & $\begin{array}{l}\text { Per } \\
\text { cent. }\end{array}$ \\
\hline $\begin{array}{cc}a & \text { (High) .. } \\
b & \\
c & \text { (Minimal) } \\
d & \text { (Low) ... }\end{array}$ & $\begin{array}{l}\cdots \\
\cdots \\
\cdots\end{array}$ & $\begin{array}{r}9 \\
24 \\
55 \\
9\end{array}$ & $\begin{array}{r}8 \\
18 \\
23 \\
2\end{array}$ & $\begin{array}{l}89 \\
75 \\
42 \\
22\end{array}$ & $\begin{array}{l}\left.\begin{array}{l}a \\
b\end{array}\right\} \text { (High) } \\
c \text { (Minimal) } \\
d \text { (Low) }\end{array}$ & $\begin{array}{l}\cdots \\
\cdots \\
\cdots\end{array}$ & $\begin{array}{l}10 \\
19 \\
68\end{array}$ & $\begin{array}{r}8 \\
14 \\
29\end{array}$ & $\begin{array}{l}80 \\
74 \\
43\end{array}$ & $\begin{array}{ll}a & \text { (High) } \\
b & \\
c & \text { (Minimal) } \\
d & \text { (Low) }\end{array}$ & $\begin{array}{l}13 \\
28 \\
31 \\
25\end{array}$ & $\begin{array}{l}10 \\
16 \\
15 \\
10\end{array}$ & $\begin{array}{l}77 \\
57 \\
48 \\
40\end{array}$ \\
\hline Total & . & 97 & 51 & 53 & Total & . & 97 & 51 & 53 & Total & 97 & 51 & 53 \\
\hline \multicolumn{5}{|c|}{$x^{2}=15 \cdot 46,3$ d.f., $p<\cdot 01$} & \multicolumn{5}{|c|}{$\begin{array}{l}\chi^{2}=8 \cdot 98,1 \text { d.f., } p<\cdot 01 \\
\text { (ratings } a, b, c \text { by rating } d \text { ) }\end{array}$} & \multicolumn{4}{|c|}{$\chi^{2}=5 \cdot 11,3$ d.f., $p>\cdot 10$} \\
\hline
\end{tabular}

TABLE VI

BEHAVIOUR OF PATIENT AND PROPORTION OF PATIENTS WHO DETERIORATED

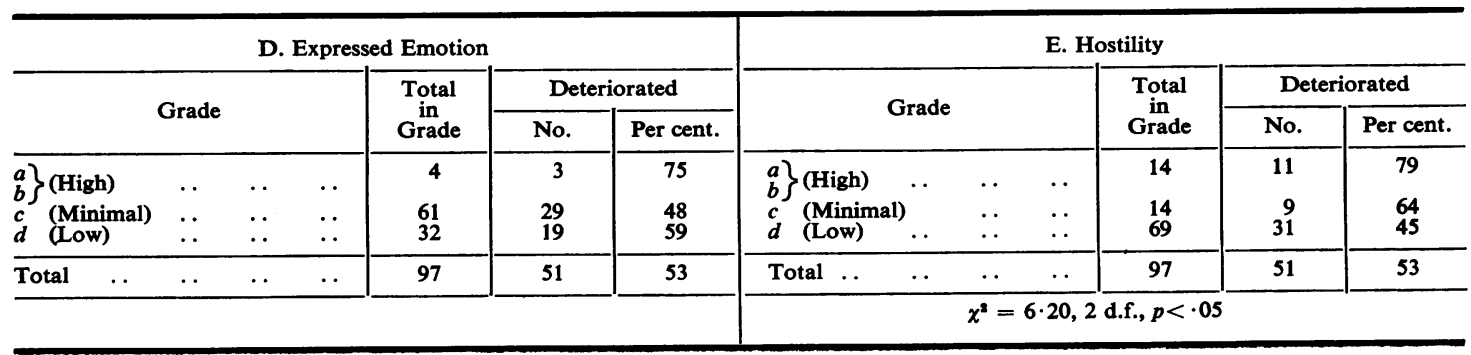


hostile lived with a relative who showed some hostility, or high "expressed emotion", or both. On the other hand, only 27 (39 per cent.) of the 69 patients rated low in hostility lived with a relative who showed at least minimal hostility or high "expressed emotion".

This analysis indicated that the classification of families could be simplified in order to test the hypotheses. Patients were placed in "high" or "low emotional involvement" groups, according to whether the key relative was rated either $a$ or $b$ on "expressed emotion", or $a, b$, or $c$ on "hostility".

By this means the families were conveniently divided into two nearly equal groups: fifty patients living with relatives who showed "high emotional involvement", and 47 with relatives who showed "low emotional involvement" (Table VII).

\section{(5) The Two Hypotheses}

(i) Influence of Emotional Involvement in the Home.-Table VII shows that 76 per cent. of patients returning to "high emotional involvement" homes, in contrast to 28 per cent. returning to "low emotional involvement" homes, deteriorated in behaviour. This large difference is statistically

\section{TABLE VII}

“EMOTIONAL INVOLVEMENT" LEVEL OF KEY RELATIVE AND PROPORTION OF PATIENTS WHO DETERIORATED

\begin{tabular}{c|c|c|c|c|c}
\hline Level & $\begin{array}{c}\text { Not } \\
\text { Deteriorated }\end{array}$ & Deteriorated & Total & Deteriorated \\
Percentage & $\begin{array}{c}\text { Per- } \\
\text { centage } \\
\text { Re- } \\
\text { admitted }\end{array}$ \\
\hline High & 12 & 38 & 50 & 76 & 56 \\
\hline Total & 34 & 13 & 47 & 28 & 21 \\
\hline & 46 & 51 & 97 & 53 & 39 \\
\hline \multicolumn{4}{|c|}{$\chi^{2}=22 \cdot 70,1$ d.f., $p<\cdot 001$} & \\
\hline
\end{tabular}

significant and persists when re-admission to hospital is used as an alternative criterion of outcome-56 per cent. were re-admitted from "high" and 21 per cent. from "low emotional involvement" homes.

To test whether this result was influenced by the definition of "emotional involvement", various alternative methods of sorting were used (such as using information from all five scales of "emotional involvement"), but similar results were obtained.

Table VIII shows that this difference also remains when mental state ratings at discharge are allowed for. Of patients with mental state ratings of 1 and 2, 64 and 14 per cent. deteriorated in "high" and "low emotional involvement" homes respectively. Of those with mental state ratings of 3 or 4 , the corresponding figures are 81 and 40 per cent. These differences are statistically significant. When both mental state and socially embarrassing behaviour scores were analysed, the difference still persisted; the difference was not reduced from that observed when mental state scores were taken alone. The relationship also held whether the patient returned to parents, wife, or more distant kin.

Serious anti-social behaviour at the time of readmission or follow-up was defined by destructive behaviour, violence, threats of violence, attempted suicide, or seriously disturbed sexual behaviour. 29 per cent. of the patients scored positively on at least one of these items. Two-thirds of the 38 patients who deteriorated in "high", in contrast to only one-third of the thirteen deteriorating in "low emotional involvement" homes, were disturbed in this way $\left(\chi^{2}=4 \cdot 11,1\right.$ d.f., $\left.p<\cdot 05\right)$.

(ii) Influence of Amount of Face-to-face Contact with Relatives in the Home.-It was predicted that patients living in "high emotional involvement" homes would do better the less they saw

TABLE VIII

PERCENTAGE OF PATIENTS WHO DETERIORATED BY "EMOTIONAL INVOLVEMENT" LEVEL OF KEY RELATIVE AND MENTAL STATE AT DISCHARGE

\begin{tabular}{|c|c|c|c|c|c|c|c|c|c|c|c|}
\hline \multirow{3}{*}{\multicolumn{4}{|c|}{$\begin{array}{c}\text { Emotional Involvement } \\
\text { Level }\end{array}$}} & \multicolumn{8}{|c|}{ Mental State (degree of disturbance) } \\
\hline & & & & \multicolumn{4}{|c|}{ None and Minimal (1 and 2) } & \multicolumn{4}{|c|}{ Moderate and Severe (3 and 4) } \\
\hline & & & & $\begin{array}{c}\text { Not } \\
\text { Deteriorated }\end{array}$ & Deteriorated & Total & $\begin{array}{c}\text { Percentage } \\
\text { Deteriorated }\end{array}$ & \begin{tabular}{|c|} 
Not \\
Deteriorated
\end{tabular} & Deteriorated & Total & $\begin{array}{c}\text { Percentage } \\
\text { Deteriorated }\end{array}$ \\
\hline $\begin{array}{l}\text { High } \\
\text { Low }\end{array}$ & 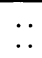 & $\begin{array}{l}\ldots \\
\ldots\end{array}$ & 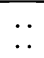 & $\begin{array}{r}5 \\
19\end{array}$ & $\begin{array}{l}9 \\
3\end{array}$ & $\begin{array}{l}14 \\
22\end{array}$ & $\begin{array}{l}64 \\
14\end{array}$ & $\begin{array}{r}7 \\
15\end{array}$ & $\begin{array}{l}29 \\
10\end{array}$ & $\begin{array}{l}36 \\
25\end{array}$ & $\begin{array}{l}81 \\
40\end{array}$ \\
\hline \multirow[t]{2}{*}{ Total } & $\ldots$ & . & . & 24 & 12 & 36 & 33 & 22 & 39 & 61 & 64 \\
\hline & & & & \multicolumn{4}{|c|}{$x^{2}=9 \cdot 86,1$ d.f., $p<\cdot 01$} & \multicolumn{4}{|c|}{$x^{2}=10 \cdot 51,1$ d.f., $p<\cdot 01$} \\
\hline
\end{tabular}


of the key relative. In order to divide the patients into two approximately equal groups, those spending less than 35 hours per week in personal contact with this relative before any deterioration had taken place were defined as "low contact" (48 per cent. of patients) and the rest as "high contact". Table IX shows that patients who were moderately or severely disturbed in mental state at discharge, and who returned to "high emotional involvement" homes, deteriorated less frequently when they spent less than 35 hours per week with the key relative $\left(\chi^{2}=8 \cdot 00,1\right.$ d.f., $p<\cdot 01$; Yates correction applied). For patients in the two least disturbed mental state categories and for those living in "low emotional involvement" homes, "low contact" was not associated with a lower deterioration rate.

The second hypothesis is thus confirmed, but only for patients leaving hospital moderately or severely disturbed and returning to homes with a high level of "emotional involvement".

\section{(6) Further Analysis}

The association between "high emotional involvement" and deterioration might be largely dependent upon clinical condition at discharge and features of the past course of the illness.

Mental state at discharge was one of the measures most highly related to "emotional involvement": 59 per cent. of those showing moderate or severe, in contrast to 39 per cent. showing none or minimal, disturbance returned to "high emotional involvement" homes. This does suggest that some of the high emotion shown by relatives was elicited by the patient's disturbed behaviour at discharge. There was also some evidence that his past history had influenced relatives. The pre-discharge item most highly related to deterioration was the amount of unemployment during the 2 years before discharge. This was also related to the emotional involvement ratings. Of the 51 patients with more than 12 months' unemployment, 32 (63 per cent.) returned to "high emotional involvement" homes; by comparison the proportion was eighteen out of 46 (39 per cent.) in those with less than 12 months' unemployment. However, when this factor and mental state are both taken into account, the main relationship between emotional involvement and deterioration does not disappear (see Table $\mathbf{X}$ ).

TABLE IX

OUTCOME BY MENTAL STATE AT DISCHARGE, "EMOTIONAL INVOLVEMENT" IN THE HOME, AND AMOUNT OF CONTACT WITH KEY RELATIVE

\begin{tabular}{l}
\hline \multirow{2}{*}{$\begin{array}{c}\text { Levels of Contact and } \\
\text { "Emotional Involvement" of } \\
\text { Key Relative }\end{array}$} \\
\cline { 2 - 10 }
\end{tabular}

TABLE X

EMPLOYMENT IN 2 YEARS BEFORE DISCHARGE BY MENTAL STATE AT DISCHARGE AND "EMOTIONAL INVOLVEMENT" IN THE HOME, SHOWING PERCENTAGES OF PATIENTS WHO DETERIORATED

\begin{tabular}{|c|c|c|c|c|c|c|c|c|c|c|c|c|c|c|}
\hline \multirow{3}{*}{$\begin{array}{c}\text { Months of } \\
\text { Unemployment } \\
\text { in the } 2 \text { years } \\
\text { before } \\
\text { Discharge }\end{array}$} & \multirow{3}{*}{\multicolumn{2}{|c|}{$\begin{array}{l}\text { Level of } \\
\text { "Emotional } \\
\text { Involvement" }\end{array}$}} & \multicolumn{8}{|c|}{ Mental State at Discharge (degree of disturbance) } & \multirow{2}{*}{\multicolumn{4}{|c|}{ Total }} \\
\hline & & & \multicolumn{4}{|c|}{ None and Minimal (1 and 2) } & \multicolumn{4}{|c|}{ Moderate and Severe (3 and 4) } & & & & \\
\hline & & & $\begin{array}{c}\text { Not } \\
\text { Deteri- } \\
\text { orated }\end{array}$ & $\begin{array}{l}\text { Deteri- } \\
\text { orated }\end{array}$ & Total & $\begin{array}{l}\text { Per- } \\
\text { centage } \\
\text { Deteri- } \\
\text { orated }\end{array}$ & $\begin{array}{l}\text { Not } \\
\text { Deteri- } \\
\text { orated }\end{array}$ & $\begin{array}{l}\text { Deteri- } \\
\text { orated }\end{array}$ & Total & $\begin{array}{l}\text { Per- } \\
\text { centage } \\
\text { Deteri- } \\
\text { orated }\end{array}$ & $\begin{array}{l}\text { Not } \\
\text { Deteri- } \\
\text { orated }\end{array}$ & $\begin{array}{l}\text { Deteri- } \\
\text { orated }\end{array}$ & Total & $\begin{array}{l}\text { Per- } \\
\text { centage } \\
\text { Deteri- } \\
\text { orated }\end{array}$ \\
\hline \multirow{2}{*}{ More than 12.} & High .. & $\cdots$ & 4 & 7 & 11 & 64 & 1 & 20 & 21 & 95 & 5 & 27 & 32 & 84 \\
\hline & Low $\quad .$. & .. & 5 & 2 & 7 & 29 & 7 & 5 & 12 & 42 & 12 & 7 & 19 & 37 \\
\hline \multirow{2}{*}{ Less than $12 \ldots$} & High .. & $\cdots$ & 1 & 2 & 3 & 66 & 6 & 9 & 15 & 60 & 7 & 11 & 18 & 61 \\
\hline & Low $\ldots$ & $\ldots$ & 14 & 1 & 15 & 7 & 8 & 5 & 13 & 38 & 22 & 6 & 28 & 21 \\
\hline
\end{tabular}


Most other pre-discharge items showed little or no relationship to "emotional involvement", e.g. age at discharge, father's occupational level, total length of stay in hospital, "disturbed" behaviour before admission, decline in occupational level before admission, and length of time since first admission. In the case of two other items, the number of previous admissions and length of key admission, the association was a little greater, but the main relationship remained when each was taken into account.

Finally, the descriptive accounts of the interviews were studied for any indication of why ratings of "high emotional involvement" were made. In about one-third of the cases, it was probable that the "high emotional involvement" of the key relative was directly due to the effects of the past or present behaviour of the patient. About another third of the ratings seemed probably due to the characteristic behaviour of the relative; and in the remaining group some complex interplay between her attitude and the developing illness was suggested.

\section{(7) LoDGINGS}

The previous work had shown fewer re-admissions amongst those returning to lodgings or siblings than amongst those returning to parents or wives. Because of this finding some patients returning to lodgings (31) were included in the present study: four of these 31 patients were not traced. Table XI shows that the previous follow-up results were not repeated for those returning to lodgings. The same proportion deteriorated as among those returning to parents and wives ( 56 per cent.), but fewer returned to hospital (33 in comparison with 46 per cent.-not significant). The seven patients returning to siblings all did well.

Either this result largely invalidates the idea that for schizophrenic patients "social isolation" can be protective, or there are special features about the patients living in lodgings in the present study which differentiate them from the other patients in this or in the previous study of long-stay patients (Brown, 1959). Since there has been support for the main hypotheses among patients living with relatives, the latter possibility seems worth examining.

There is some indication that those returning to lodgings differed as a group from the other patients. For example, one-third of them were either Irish or foreign, a far higher proportion than for the other patients. The majority had previously lived either in lodgings or hostels and many had led a vagrant life for years.

Among the twelve who did not deteriorate while living in lodgings, ten had had fairly regular contact with relatives living nearby, in contrast to only three of the fifteen who deteriorated. The previous study had suggested that to live alone but with support from nearby relatives was particularly likely to be successful.

Also notable was the number of those who deteriorated (almost half) who apparently experienced severe personal difficulties before any deterioration. For example, patients living in lodgings seem less able to overcome periods of unemployment than those living with relatives. 52 patients living with relatives worked less than three-quarters, and 49 patients worked more than three-quarters of their time out of hospital; the proportions deteriorating in these two groups were 63 and 47 per cent. respectively. However, the patients living in lodgings showed a greater difference in the proportions who deteriorated in the two work groups. Of the ten patients who worked less than three-quarters of their time out of hospital, nine (90 per cent.) deteriorated; of the seventeen who worked more than three-quarters of the time, six (35 per cent.) deteriorated.

Since the only prediction that was made concerning patients going to lodgings - that they would show

\section{TABLE XI}

PROPORTION OF PATIENTS WHO DETERIORATED AND WERE RE-ADMITTED AMONG THOSE LIVING IN LODGINGS, WITH SIBLINGS, OR WITH PARENTS AND WIVES

\begin{tabular}{|c|c|c|c|c|c|c|c|c|c|c|c|c|c|}
\hline \multirow{4}{*}{ Discharged } & & & \multicolumn{6}{|c|}{ Mental State at Discharge (degree of disturbance) } & \multirow{2}{*}{\multicolumn{5}{|c|}{ All Patients }} \\
\hline & & & \multicolumn{3}{|c|}{$\begin{array}{l}\text { None and Minimal } \\
(1 \text { and } 2)\end{array}$} & \multicolumn{3}{|c|}{$\begin{array}{c}\text { Moderate and Severe } \\
\text { (3 and 4) }\end{array}$} & & & & & \\
\hline & & & \multirow{2}{*}{$\begin{array}{l}\text { Total } \\
\text { No. }\end{array}$} & \multicolumn{2}{|c|}{ Deteriorated } & \multirow{2}{*}{$\begin{array}{l}\text { Total } \\
\text { No. }\end{array}$} & \multicolumn{2}{|c|}{ Deteriorated } & \multirow{2}{*}{ No. } & \multicolumn{2}{|c|}{ Deteriorated } & \multicolumn{2}{|c|}{ Re-admitted } \\
\hline & & & & No. & $\begin{array}{l}\text { Per } \\
\text { cent. }\end{array}$ & & No. & $\begin{array}{l}\text { Per } \\
\text { cent. }\end{array}$ & & No. & $\begin{array}{l}\text { Per } \\
\text { cent. }\end{array}$ & No. & $\begin{array}{l}\text { Per } \\
\text { cent. }\end{array}$ \\
\hline $\begin{array}{l}\text { Lodgings } \ldots \\
\text { Siblings } \ldots \\
\text { Parents and Wives }\end{array}$ & $\begin{array}{l}\ldots \\
\cdots\end{array}$ & $\begin{array}{l}. \\
\cdots \\
\cdots\end{array}$ & $\begin{array}{r}15 \\
5 \\
33\end{array}$ & $\begin{array}{r}8 \\
1 \\
13\end{array}$ & $\begin{array}{l}53 \\
20 \\
39\end{array}$ & $\begin{array}{r}12 \\
2 \\
61\end{array}$ & $\begin{array}{r}7 \\
1 \\
40\end{array}$ & $\begin{array}{l}58 \\
50 \\
66\end{array}$ & $\begin{array}{r}27 \\
7 \\
94\end{array}$ & $\begin{array}{r}15 \\
2 \\
53\end{array}$ & $\begin{array}{l}56 \\
29 \\
56\end{array}$ & $\begin{array}{r}9 \\
1 \\
43\end{array}$ & $\begin{array}{l}33 \\
14 \\
46\end{array}$ \\
\hline Totals & $\cdot$ & $\ldots$ & 53 & 22 & 42 & 75 & 48 & 64 & 128 & 70 & 55 & 53 & 41 \\
\hline
\end{tabular}


a lower deterioration rate than patients with parents or wives-was not borne out, these interpretations must be treated with caution.

\section{Discussion}

Studies seeking to predict the outcome of schizophrenia have used two groups of factors: those relating to the past course and severity of the illness (e.g. number of previous admissions or length of time since onset), and those relating to clinical condition at discharge. The size of the associations, as in this study, has usually been small (Malamud and Render, 1939; Chase and Silverman, 1943; Schofield, Hathaway, Hastings, and Bell, 1954; Ellsworth and Clayton, 1959). For example, Schofield and others (1954) abstracted 200 items from case notes but found only seventeen related to their measures of outcome. This study has been concerned with a third factor-the effect of the relationship of the patient with his family on the course of an established illness. The predictions were that a patient's behaviour would be more likely to deteriorate when he returned to a home in which strongly expressed emotion, hostility, or dominating behaviour was shown towards him by a family member. Further, that even in such circumstances deterioration might be avoided if the amount of personal contact with this family member was low.

The first hypothesis was confirmed. The deterioration rate was higher among those returning to homes in which "high emotional involvement" was shown by relatives at the time of discharge; three-quarters became worse in behaviour in contrast to less than one-third of the remaining patients. This held whether the patient returned to parents, wife, or more distant kin. The second hypothesis was confirmed only for patients discharged moderately or severely disturbed in mental state and where the key relative (usually a wife or mother) showed "high emotional involvement". In these circumstances a small number of hours spent with her during each day was associated with a better outcome. It was also found that serious anti-social behaviour in the home, such as destructiveness and violence, was associated more often with those who deteriorated in "high" rather than in "low emotional involvement" homes.

Some confidence may be placed in these findings, since the measures on which the predictions were based could not have been influenced by any knowledge of outcome. Ratings of family relationships were always made before the follow-up interviews. However, a causal relationship is not necessarily indicated. Although the home situation, the past course of the illness, and condition at discharge were all related to deterioration, the findings could still be entirely due to clinical differences. The greater frequency of "high emotional involvement" among the relatives of patients who deteriorated could be the result of their reactions to the patient's past or current disturbance. If this were the case, the patients would be expected to deteriorate whatever the home situation, and the association between "high emotional involvement" and deterioration would disappear when clinical and other predischarge factors were taken into account. However, when this was done, the association was still present, though weaker, suggesting that at least in some cases the home relationships had played a direct part in the patient's deterioration.

Although evidence has been provided that personal relationships in the home can influence the course of an established schizophrenic illness, the study was not designed to investigate the processes leading to the different forms of relationship. However, three observations which arise from this work, although speculative, may be useful in future research:

(1) There seemed to be a wide variation in the response of relatives to the same kind of psychotic behaviour: some wives, for example, remained tolerant and pleasant towards their husbands in the presence of behaviour to which other wives reacted with antagonism. Variation also occurred over time, some relatives changing noticeably in their behaviour and feelings towards the patient. One wife, for example, described how at first she responded with irritation and intolerance to her husband's illness; very bad quarrels were associated with his psychotic episodes. But over the years she found that ignoring his provocative behaviour avoided a good deal of trouble and made a tolerable family life possible. Some people seem to react like this from the beginning of the illness and others do their best to change but fail. Another wife described how she was never able to keep for long from showing her irritation or to suppress her belief that her husband was "not really ill".

(2) Patients can often show some control over the expression of their disorder, and this may be influenced by environmental factors. It was fairly common to be told by the relatives of a disturbed patient that, when strangers called or he visited the doctor, "he is like you or me". The most startling examples of this came from a few employers who reported quite acceptable conduct in patients who at home had behaved in a very disturbed manner.

(3) The degree of personal contact with the patient is often an important factor in determining the tolerance of relatives. One example will illustrate this and the previous point. 
The patient had been ill for 5 years but, in spite of lengthy hospital admissions and frequent auditory hallucinations throughout the year, he worked steadily in an unskilled job. His mother said that his behaviour often became much worse after spending the week-end at home. It was on a Sunday evening that he was most likely to accuse her of causing his voices and to threaten and sometimes strike her. Life was bearable for his parents only while contact was reduced during the rest of the week by his full-time work.

The descriptive accounts of interviews suggested that the families in which "high emotional involvement" was shown could be divided into two main and one residual group on the basis of these three points. In about one-third of the interviews it seemed that the past or current behaviour of the patient was a sufficient cause of the "high emotional involvement" of their relatives. In these cases the relatives' reactions seemed least likely to have affected the illness after discharge. In roughly another third the "high emotional involvement" was clearly due to the unusual behaviour of the relative, and could be independent of the severity of illness of the patient. Many of these relatives were mentally ill themselves-several had been in mental hospitals-and genetic factors may have been involved. The remaining families could be included in neither group, and it is possible that an interaction between the behaviour of the patient and that of the relative was responsible for the "high emotion". In the following example the patient's parents had good reason to fear him, but nevertheless their behaviour towards him could be described as provocative:

The patient had returned from his fifth admission in 5 years, showing no symptoms except severe apathy. At recent admissions he had been violent toward one or other parent and when seen a fortnight after discharge his mother was very hostile. She shouted at him: "You'll have to go or there will be a tragedy. I'll do you in, I really will", and many similar remarks. At this time the patient made no response. Within 2 months he had deteriorated and was re-admitted after an incident in which he attacked his father after the latter had thrown a plate at him. Both parents said afterwards that they had known he would be violent. The patient had undoubtedly stirred up their hostility by his unco-operative manner, demands for food and money, and refusal to try for a job. Yet the father did admit that he had started the final quarrel, and from the very start of the illness there was evidence that the mother had shown unusual behaviour; for instance, when he left his grammar school she burned his books against his wishes.

For the group of men going to lodgings the problems appear to be different. Both this and the previous follow-up study of long-stay patients suggest that certain forms of social isolation can be beneficial for the discharged schizophrenic patient, but the poorer outcome of these men in the current study shows that living away from one's family may not be the most important factor. Discrepancies in the findings of the two studies may have occurred partly because home relationships were particularly difficult for the patients in the previous follow-up study. This was suggested by the fact that some moved to lodgings apparently only after home life had become unbearable. Lack of any supportive ties may be just as harmful for a schizophrenic as ties involving tension and hostility; a few patients described the loneliness they felt when in lodgings, even though they realized that they were "better" away from home. These patients seem to find it particularly difficult to overcome personal crises such as unemployment or illness. A large proportion of those living in lodgings were Irishmen or foreigners, and had no family in England; a history of vagrancy and migration up and down the country was common.

Experimental studies in which the patient can be offered facilities such as sheltered work and hostel accommodation are needed to investigate the problems of discharged schizophrenics. Only in this way will it be possible to control some of the confounding factors and assess more satisfactorily the degree of importance to be given to social factors.

\section{SUMmary}

(1) 128 schizophrenic men were followed-up for one year after leaving hospital. All patients were assessed on severity of symptoms by a psychiatrist just before discharge. 101 patients were seen at home with their relatives 2 weeks after discharge and assessed on the amount of "expressed emotion" shown towards each other. At the time of any re-admission during the year, and at the end of the year, details of the patient's behaviour were obtained from relatives and other sources. 27 patients who lived in lodgings or alone were seen at readmission and at the end of the year.

(2) 55 per cent. deteriorated during the yearthree-quarters of these patients were readmitted at least once during the year.

(3) The first hypothesis was that patients returning to a relative who showed "high emotional involvement" (based on measures of "expressed emotion", hostility, and dominance) would deteriorate more frequently than patients returning to a relative who showed 
"low emotional involvement". This hypothesis was confirmed.

(4) The second hypothesis was that, if the patient lived with relatives showing "high emotional involvement" at the time of discharge, a small or average number of hours spent each week with the relatives would reduce the frequency of deterioration. This hypothesis was confirmed only for patients who were moderately or severely disturbed at discharge.

(5) The larger proportion of patients who deteriorated when living with relatives who showed "high emotional involvement" is not explained by differences in the clinical condition of the patients at discharge. The possibility of a causal relationship is discussed.

(6) The proportion of patients who deteriorated amongst those living in lodgings and those living with relatives was similar.

Our thanks are due to the mental hospital Medical Superintendents for permission to do the work, and to the clerical and nursing staff of the hospitals for the help and co-operation they showed in many important details of the study.

\section{REFERENCES}

Brown, G. W. (1959). Milbank Mem. Fund Quart., 37, 105.

, Carstairs, G. M., and Topping, G. (1958). Lancet, 2,685 .

Chase, L. S., and Silverman, S. (1941). Amer. J. Phychiat., 98, 360 .

Ellsworth, R. B., and Clayton, W. H. (1959). J. consult. Psychol., 23, 15.

Freeman, R. V., and Grayson, H. M. (1955). J. abnorm. soc. Psychol., 50, 45.

Gerard, D. L., and Siegel, J. (1950). Psychiat. Quart., $24,47$.

Hotchkiss, G. D., Carmen, L., Ogilby, A., and Wiesenfeld, S. (1955). J. nerv. ment. Dis., 121, 452.

Kasanin, J., Knight, E., and Sage, P. (1934). Ibid., 79, 249.

Kohn, M. L., and Clausen, J. A. (1956). Amer. J. Orthopsychiat., 26, 297.

Malamud, W., and Render, N. (1939). Amer. J. Psychiat., 95, 1039.

Mark, J. C. (1953). J. abnorm. soc. Psychol., 48, 185.

Nielsen, C. K. (1954). Acta psychiat. neurol. scand., 29, 281.

Schofield, W., Hathaway, S. R., Hastings, D. W., and Bell D. M. (1954). J. consult. Psychol., 18, 155.

Tietze, T. (1949). Psychiatry, 12, 55.

\section{APPENDIX}

Examples of Ratings on Five Scales of "EMOTIONAL INVOLVEMENT" MADE AT INTERVIEW with Patient and Key Relative(s) 2 Weeks AFTER DISCHARGE

(a) Uncontrolled Emotion frequently Shown (104).-The patient had shown a gradual decline of interests over a number of years, and did not mind being dependent on his 58-year-old mother who went out to work.

In the interview he behaved in a normal manner, but his mother talked almost continuously, repeating " $\mathrm{He}$ is unemployed, that is the bottom of it", and showed a great deal of hostility towards doctors, etc. These accusations seemed to have a paranoid colouring. The son remained calm, although he walked out of the room twice while she was talking, and was recalled in a peremptory way by his mother. Finally she became very incoherent and the interviewer was unable to follow much of what she said.

(b) Conspicuous Emotion Shown, but under Some Degree of Control (9).-A 39-year-old man with a long history of mental illness, was discharged to his parents after 12 years in hospital. The mother spent most of the interview "protecting" her son from the interviewer: answering questions for him, "translating" their meaning for him, butting in, etc. She watched him a lot and said many times how very nice it was to have him home once again properly.

(c) Emotion Shown but well Controlled: Noticeable only in Response to some Strong Stimulus (17).-A man, aged 36 who had worked most of his life on his parents' smallholding in Ireland, came to live with his married sister in England and returned home to her and to a job as a stoker which he had held before his key admission. His sister described their mutual affection and this was quite evident in the interview.

(d) No Emotion Expressed: Evidence of Indifference or Casualness (11).-A patient with a long history of psychiatric disturbances left hospital without symptoms to live with his mother and married brother. At the interview the whole family sat together but said very little. Replies to questions were always short, the mother usually answering in monosyllables. They did not address each other: all interaction was with the interviewer. The mother said, as she showed the interviewer out, that they rarely spoke and that her married son usually stayed in his own room with his wife. 
EMOtion EXPRESSED by PATIENT towards Key RELATIVE

(a) Uncontrolled Emotion frequently Shown (72).-A married man with five previous hospital admissions for paranoid schizophrenia was transferred from certified to voluntary status without his wife's knowledge and left hospital at once against her wishes. Both were openly angry with each other throughout the whole interview, the wife saying little but interrupting with bitter comments from time to time. The patient hinted that she was plotting to put him away.

(b) Conspicuous Emotion Shown, but under Some Degree of Control (136).-A young married Irishman, who had been ill for 6 years and had had three short admissions, returned to his wife and child (aged 3). They were all living in one room. He was very ready to discuss his symptoms and faults: for example, his quick temper (there had been blows with his wife the night before). He showed affection for his wife but also hostility from time to time, several times accusing her, for example, of putting the baby first.

(c) Emotion Shown but well Controlled: Noticeable only in Response to some Strong Stimulus (21).-A married man with one child, returned to his wife and former job. He was very talkative and showed no reticence in discussing his illness and relationship with his wife. They talked about their differences (for example, whether she should work), but did so in a relaxed way without any noticeable excitement.

(d) No Emotion Expressed: Evidence of Indifference or Casualness (26). - A man aged 31, who had first been admitted while still at school, returned to his parents. Throughout the interview he showed no emotional response to them: he spoke only when directly questioned and otherwise stared into space. No amount of questioning about the difficult life of the household produced any show of involvement.

\section{Hostility EXPREsSed by Key Relative towards Patient}

(a) Marked Rejection or Hostility shown in Behaviour (26).-A man aged 31 with a long history of schizophrenic illnesses returned to his parents. He remained apathetic throughout the interview, but his mother was very excited and said many hostile things: "He'll have to goit's him or me. I can't stand it any longer. If he stays, there'll be a tragedy-I'll do him in. I really will', etc.

(b) Definite Hostility, but not often observed in Open Form (80).- After his third admission a 30-year-old man returned to his crippled mother and elderly father. The mother reacted sensibly to her son's persistent disregard of her remarks, and she seemed prepared to tolerate him as long as he was not an active nuisance-" "He's quiet enough". Nevertheless, over an argument about whether the interviewer should have margarine on a bun or not, she practically hit her son and became very quickly upset.

(c) Minimal Evidence (57).-A man aged 32, who had been ill since 1955 and had behaved very badly towards his mother in his disturbed spells, returned to his parents after 2 months in hospital. The patient was sensible and co-operative and seemed to enjoy talking. His mother's hands shook and she had difficulty in forcing a smile, but there was only slight evidence of any hostility on her part. She suggested in a tentative way that he might like to live away in lodgings so that he could find more friends. He said he did not like the idea.

(d) No evidence (35).-A married man with four children, who had a history of 12 years' anxiety and ideas of persecution, returned after his third admission of 3 months to his wife. She is an easygoing, level-headed woman, who could foresee the difficulties that would arise from her husband's unemployment, but did not tax him about his inefficiency, etc. She sees herself as someone who manages so that he will not have to worry.

\section{Hostility Expressed by Patient towards Key Relative}

(a) Marked Rejection or Hostility shown in Behaviour (52). - A man who had been in hospital 3 months on his second admission, returned to his comfortably-off parents. At interview the mother was very worried and anxious about him. The patient appeared nonchalant and off-hand and never smiled. He was not shy but rather aggressively indifferent, making many hostile remarks to his mother. For example, aggressively thrusting his head forward, he would say, "I did that job for you yesterday, didn't I? Isn't that enough now? That's all right now, Mum. You leave me alone."

(b) Definite Hostility, but not often observed in Open Form (105). A man aged 43 returned to his invalid wife after his first admission. During the interview his hostility to her was his only marked response. He received her remarks and suggestions with exasperated sighs, waiting for her to finish so that he could explain to the interviewer. He was mainly exasperated because she could not understand his delusional ideas: "Edith, you don't know what you are talking about", etc.

(c) Minimal Evidence (108).-A man returned to his wife and two small children after his first attack of paranoid schizophrenia. His wife was extremely quiet and submissive in manner and he did nearly all the talking. He showed affection for his wife and children but spoke to her sharply once or twice over trivial points.

(d) No Evidence (26).- A man aged 31 with a long history of schizophrenic illnesses returned to his parents. He spoke only when directly addressed and remained apathetic. The only thing he said to his mother was an easygoing remark when she brought up the question of his returning to hospital, "Oh, don't bring that topic up again". 
Dominant Behaviour by Key Relative towards Patient

(a) Very Marked and Continuous (104).-The patient had shown a gradual decline of interests over a number of years. During the interview he behaved in a sensible and normal way but his mother talked excitedly most of the time. She issued several orders to her son: "Get the card, John". Twice he walked out of the room as she talked, but she called him back: "John, come here". She constantly referred to her son as "him" while he was in the room.

(b) Not Marked but Unmistakable (9).-A 39-year-old man with a long history of mental illness returned to his parents after 12 years in hospital. His mother very frequently answered questions for him and her conversation was punctuated by remarks like: "They were very helpful, weren't they, Jack? You wouldn't mind what job it was, would you, Jack?" She watched him closely all the time and once brushed cigarette ash off his shirt.

(c) "Normal" or Minimal (4).-The patient had been morbidly jealous of his wife since her first pregnancy 10 years before, and returned to her after a first admission of 2 months. Previously she had had considerable trouble with his mother who had fed him with ideas of his wife's infidelity, etc. She was determined that his mother should keep away and the patient seemed to accept this without demur. But she also asked if he would mind if she showed the interviewer a letter about a job. They said they "discussed" everything.

(d) No Evidence (27). - A man aged 21 who had had three admissions to hospital, the last one lasting 10 months, returned to his parents, who were living in a small flat. His mother tended to talk of him as though he was not in the room, but deferred to him over points in the discussion and showed concern to please him. 